\title{
THE INVESTIGATION OF THE TEACHERS' VIEWS ABOUT THE IMPLEMENTATION OF THE COOPERATIVE LEARNING METHOD IN THE SIXTH GRADE MATHEMATICS CURRICULA REGARDING SEVERAL VARIABLES
}

\author{
Fatma ERDOĞAN*
}

\author{
Kürşat YENİLMEZ ${ }^{* *}$
}

\begin{abstract}
This research aims to determine the teachers' views about the implementation of the cooperative learning method in the sixth grade mathematics curricula which started to be implemented in the 2006-2007 academic year. Participants were 101 sixth grade mathematics teachers who were randomly selected from the elementary schools in Eskişehir. Data were collected by a questionnaire which was developed by the authors. Percentage, frequency tables, Mann- Whitney $U$ and Kruskal Wallis tests were used in the process of data analysis. It was found that there were no significant differences in terms of the variables of gender and experience of teachers, but there were significant differences in terms of the variables of the school the person graduated, having education about the cooperative learning method, having education about the $6^{\text {th }}$ grade mathematics curricula and being interested in the editions about mathematics. These findings show that mathematics teachers were open to use alternative learning methods like cooperative learning in the sixth grade mathematics curricula.
\end{abstract}

Key Words: Mathematics teaching, cooperative learning method, $6^{\text {th }}$ grade mathematics curricula

\footnotetext{
* Mathematics Teacher, e-mail: fatmayayla83@mynet.com

** Assist. Prof. Dr.,, Eskișehir Osmangazi University, e-mail: kyenilmez@ogu.edu.tr *** This research is a part of dissertation thesis.
} 


\section{SUMMARY}

Purpose and significance: The purpose of this study is to determine the teachers' views about the implementation of the cooperative learning method in the sixth grade mathematics curricula which started to be implemented in the education year of 2006-2007. It is necessary to determine which methods, which were used in educational period, would be more effective and in the base of it to have precautions to rebound the success to construct a more effective mathematics curricula in the current conditions. In this study, teachers' views were investigated to explore the implementation of the cooperative learning method in the sixth grade mathematics curricula.

Method: The survey method was used in this descriptive study. Study is bounded by the data in 2006-2007 academic year. Participants were 101 sixth grade mathematics teachers who were randomly selected from the primary schools in Eskişehir. Data were analyzed by frequency tables, Mann- Whitney U and Kruskal Wallis tests.

Results: The findings indicate that there were no significant difference in terms of the variables of gender and experience of teachers, but there were significant differences in terms of the variables of the school the person graduated, having education about the cooperative learning method, having education about the sixth grade mathematics curricula and being interested in the editions about mathematics in teachers' views about the implementation of the cooperative learning method in the sixth grade mathematics curricula which started to be implemented in the education year of 2006-2007.

Discussion and Conclusions: The findings indicate that teachers' views about the implementation of the cooperative learning method in the sixth grade mathematics curricula which started to be implemented in the education year of 2006-2007 were generally positive. These positive views might be related to their experiences and in-service educations about cooperative learning method. This study is limited to implementation of the cooperative learning method in the sixth grade mathematics curricula; therefore, more research is needed to further explore the teachers' opinions about the other modern learning methods with different variables. 


\section{ALTINCI SINIF MATEMATIKK ÖĞRETIM PROGRAMINDA İŞBİRLİĞİNE DAYALI ÖĞRENME YÖNTEMININ KULLANILABILIRLIĞINNE ILIŞKINN ÖĞRETMEN GÖRÜŞLERININ BAZI DEĞISSTKENLER AÇISINDAN İNCELENMESİ}

\section{Fatma ERDOĞAN*}

\author{
Kürşat YENILMEZ ${ }^{* *}$
}

ÖZ. Bu araştırma, 2006-2007 öğretim yılında uygulamaya konulan ilköğretim 6 . sınıf matematik öğretim programında işbirliğine dayalı öğrenme yönteminin kullanılabilirliğine ilişkin öğretmen görüşleri ile bununla ilişkili olabilecek bazı değişkenler arasındaki ilişkilerin belirlenmesi amacıyla gerçekleştirilmiştir. Araştırmanın örneklemini, Eskişehir il merkezinde bulunan ilköğretim okullarında görev yapmakta olan ve 6 . sinıfları okutan matematik öğretmenleri arasından rastlantısal olarak seçilen 101 matematik öğretmeni oluşturmaktadır. Verilerin toplanması aşamasında araştırmacı tarafından geliştirilen veri toplama aracı kullanılmıştır. Toplanan verilerin çözümlenmesinde yüzde ve frekans hesaplamaları yapılmış, Mann-Whitney $U$ ve Kruskal Wallis testlerinden yararlanılmıştır. Araştırma sonuçlarına göre, öğretmenlerin 6. sınıf matematik öğretim programında işbirliğine dayalı öğrenme yönteminin kullanılabilirliğine ilişkin görüşleri arasında cinsiyet ve meslekteki hizmet süresi değişkenlerine göre anlamlı bir farklılık bulunmadığı; mezun olunan kurum, işbirliğine dayalı öğrenme yöntemi ile ilgili hizmet içi eğitim alma, 6. sınıf matematik öğretim programıyla ilgili hizmet içi eğitim alma ve matematikle ilgili yayın izleme durumlarına göre ise anlamlı farklılıklar olduğu belirlenmiştir.

Anahtar Sözcükler: Matematik öğretimi, işbirliğine dayalı öğrenme yöntemi, 6. sınıf matematik öğretim programı

\footnotetext{
*Matematik Öğretmeni, e-posta: fatmayayla83@mynet.com

** Yard. Doç. Dr., Eskişehir Osmangazi Üniversitesi Eğitim Fakültesi Ortaöğretim Fen ve Matematik Alanlar Eğitimi Bölümü E-posta: kyenilmez@ogu.edu.tr
} 


\section{GİRiș}

Yeni bir yüzyıla girerken dünya toplumlarında yoğun bir değişim süreci yaşanmaktadır. Kuşkusuz bu değişimi en çok hisseden ve yaşaması gereken kurumlardan biri eğitim kurumlarıdır. Eğitimi yeniden gözden geçirmek ve ele almak bu çağa uyum sağlayabilmek için kaçınılmaz bir olgu olarak karşımıza çıkmaktadır (Erdoğan, 2002; Şişman, 2002). Eğitim araştırmacıları 17. yüzyıldan itibaren öğretme ve öğrenme bilimi alanında yapılandırmacılığa yönelik birçok araştırma yapmışlardır (Bodner, 1986). Yapılan araştırmalar sonucunda, yapılandırmacı yaklaşımın fen ve matematik alanlarında büyük etkileri olduğu saptanmıştır (Olssen, 1996).

Cheung ve Taylor (1991) bilimsel bilginin, hem kişisel hem de sosyal olarak zihinde yapılandırıldığını belirtirken, Phillips (1995) 'e göre yapılandırmacılık aktif öğrenme, sosyal öğrenme ve yaratıcı öğrenme süreçlerine katkı sağlamaktadır. Bu noktada yapılandırmacı eğitimcilerin; öğrenenlere yeni bilgiyi içselleştirmelerinde veya transfer etmelerinde yardımcı oldukları ifade edilmektedir (Holloway, 1999).

Yapılandırmacı yaklaşımın öğretimsel uygulamaları, farklı kaynaklara ilişkin önceki bilgileri, yeni ve belirli kavramlarla birleştirerek, öğrencilerin hem anlamalarını hem de firsatları yapılandırmasını öngören işbirliğine dayalı öğrenme ortamlarının sağlanmasını işaret eder (Ertmer ve Newby, 1993). İşbirliğine dayalı öğrenme, öğrencilerin sosyal uyumları ve akademik başarılarını geliştirmek için öğretmenler tarafından kullanılan bir öğretim yöntemidir. Ayrıca yöntem, yardım gereken öğrencilerin, öğretmenden çok diğer arkadaşlarından yardım ve dönüt firsatı yakalayabilecekleri için öğretmenler tarafından sıkça başvurulan bir yoldur (Bryant ve Bryant, 1998).

Yapılandırmacı yaklaşım içinde işbirliğine dayalı öğrenmenin öğrencilerin grup çalışmalarıyla fikirlerini paylaşma, tartışma, sunum yapma, fikrini savunma, düşüncelerini ifade etme, arkadaşlarının fikirlerine saygı duyma ve soru sorma becerilerine olumlu katkı sağladığı belirlenmiş̧tir (Arslan ve Şahin, 2004). İşbirliğine dayalı öğrenme ortamları, öğrencilerin okul boyunca akademik başarılarını, kendilerine olan saygılarını ve tutumlarını geliştirmektedir. Hem başarı düzeyi yüksek hem de başarı düzeyi düşük öğrenciler işbirliğine dayalı öğrenme gruplarından yararlanmaktadır. Birçok araştırma işbirliğine dayalı öğrenme yönteminin özellikle düşük yetenekli öğrenciler için çok büyük kazanımlar sağladığına işaret eder. $\mathrm{Bu}$ yöntemin en önemli kazanımı her düzeye ve her konuya uyarlanabilmesidir (Linkona, 1992). 
Willoughby (1990)'a göre matematik öğrenmenin tek yolu grup ile çalışmadır. Araştırma sonuçları, işbirliğine dayalı öğrenme gruplarının matematikte öğrenci başarısını arttırarak, çocukların yaşıtlarıyla iletişimi ve sosyal etkileşimi güçlendirdiğini göstermektedir (Mulryan, 1992). Problem çözme becerisi işbirliğine dayalı öğrenme yöntemiyle (İ.D.Ö.Y.) kazandırılmalıdır. Çünkü işbirliği içinde problem çözme, öğrencilerin birlikte çalışarak öğrenmelerine olanak tanırken, öğrenciler bu süreçte en üst düzey düşünme stratejilerini de kullanmaktadır (McGlinn, 1991).

Okul yıllarının başlarında öğrencilerin matematiğe karşı tutumları oldukça olumlu iken, 6. sinıfta öğrencilerin matematiğe karşı olumlu tutumlarında düşüş en yüksek düzeyine ulaşmaktadır. Bu olumsuz gidişin en önemli nedenleri, öğretim programı ve bununla bağlantılı olarak matematiği ele alışımızdaki yöntem ve teknikler olarak gösterilebilir (Olkun, 2006).

Öğrencilerin, temel ilke ve kavramları özümleyebilme, bağımsız ve yaratıcı düşünebilme, iletişim yeteneklerini geliştirmeye dayalı, ezberden uzak bir matematik öğretimi istenen ve beklenen bir öğretimdir (Özdaş, 1996). Ancak, Türkiye, 1999 yılında sekizinci sınıflar arasında yapılan ve 38 ülkenin katıldığı 3. Uluslararası Matematik ve Fen Araştırması'nda (TIMSS1999) matematikte 31. sırada, geometride ise 34. sırada yer alabilmiştir (Olkun ve Aydoğdu, 2003). PIRLS araştırma sonuçlarına göre, Türkiye 35 ülke arasında 28. sırada, uluslararası ortalamanın altındadır. Ayrıca, en kapsamlı uluslararası değerlendirme projesi olan PISA 2003'e göre Türkiye, matematikte 423 ortalama ile 30 OECD ülkesi arasında 29., değerlendirmeye katılan 41 ülke arasında 33. sırada yer almıştır (Eşme, 2005). Bununla birlikte; bilimsel ve teknolojik gelişmeler, eğitim bilimlerinde öğretmeöğrenme anlayışında gelişmeler, eğitimde kaliteyi ve eşitliği artırma ihtiyacı, ekonomiye ve demokrasiye duyarlı bir eğitim ihtiyacı, bireysel ve ulusal değerlerin küresel değerler içinde geliştirilmesi ihtiyacı, sekiz yıllık temel eğitim için öğretim programı bütünlüğünün sağlanması ihtiyacı, yatay eksende dersler arası ve dikey eksende her bir dersin kendi içinde kavramsal bütünlük sağlanması zorunluluğu nedeniyle ülkemizde uygulanan matematik öğretim programının yeni yaklaşımları ele alacak şekilde yenilenmesi gerekmektedir (TTKB, 2005).

Nitelikli bireyler yetiştirmenin nitelikli öğretim programlarıyla gerçekleşeceği düşüncesiyle 2004-2005 öğretim y1lı başında oluşturulan MEB-TTKB komisyonunun çalışmalarıyla, öğrenci merkezli anlayışı temel alan ve yapılandırmacı öğrenme yaklaşımına uygun olarak ilköğretim matematik öğretim programları yenilenmiş ve II. kademe için 2006-2007 öğretim yılında yeni program uygulamaya konulmuştur. 
Yenilenen 6. sınıf matematik öğretim programında eğitimde yapılandırmacı yaklaşım benimsenmiştir. Öğrencilerin matematik yapma sürecinde etkin katılımcı olması 6. sınıf matematik öğretim programının asıl hedeflerinden biridir. $\mathrm{Bu}$ hedefin gerçekleşmesi için, matematik öğretim ortamlarının, öğrencilerin çevreleriyle etkileşimde bulunabilecekleri, bilgilerinin doğruluğunu sınayıp yanlışlarını düzeltebilecekleri, araştırma yapıp keşfedebilecekleri, problem çözüp çözümlerini tartışabilecekleri işbirliğine dayalı öğrenmeyi sağlayacak şekilde düzenlenmesi gerekir (Ersoy, 2006; Pesen, 2006).

İşbirliğine dayalı öğrenme yönteminin zor ve karmaşık işlerin gerçekleştirilmesinde kullanılan üst düzey bilişsel stratejiler (sınıflama, geri getirme, kavram geliştirme, problem çözme, akıl yürütme vb.) üzerinde olumlu etkilerinin bulunduğunu; işbirliğine dayalı öğrenme gruplarında çalışan öğrencilerin üst düzey bilişsel stratejileri daha sık kullandıklarını gösteren bir çok araştırma bulgusu (Laughlin, 1973; Johnson, et al., 1980; Sharan, et al., 1980, Johnson ve Johnson, 1986; Lazarowitz ve Karsenty, 1990) vardır (Akt. Açıkgöz, 1992). 6. sınıf matematik öğretim programının hedeflediği ortak beceriler ve alana özgü becerilerin geliştirilmesinde işbirliğine dayalı öğrenme yöntemi tekniklerinin kullanılmasının katkı sağlayacağı açıktır.

6. sınıf matematik öğretim programında, öğrencilerde matematiksel kavram ve beceriler geliştirilirken duyuşsal gelişimin de göz önünde bulundurulması gerektiği vurgulanmaktadır. Tutum diğer duyuşsal özellikler gibi kişinin yaşantılarından ve başka kişilerle olan etkileşiminden önemli ölçüde etkilenir. Yapılan araştırmalar (DeVries ve Slavin, 1978; Slavin, 1990; Okebukola, 1986; Aç1kgöz, 1990; Solomon, 1990) İ.D.Ö.Y.'ün öğrencinin okul ve öğrenme ile ilgili tutumlarını olumlu yönde etkilediğini göstermektedir (Akt. Açıkgöz, 1992).

İşbirliğine dayalı öğrenme yönteminin ilkeleri, öğrencilerin grup içindeki etkileşimlerinin öğrenmede önemli bir rol oynadığı ve grup başarısı için her öğrencinin üstlendiği rolü gerçekleştirmesini vurgulamaktadır. Programda hedeflenen öz düzenleme becerileri ve psikomotor becerilerin kazandırılması gerekliliği ile işbirliğine dayalı öğrenme yönteminin ilkeleri arasında paralellik olduğu görülmektedir.

Yeni 6. sınıf matematik öğretim programı ise özel bir yöntem önermemekle birlikte verdiği etkinlik örneklerinde daha çok işbirliğine dayalı, araştırmacı ve öğrencinin kavram oluşturmasına yönelik yöntemlerin kullanılmasını önermektedir (Olkun, 2006). Ayrıca, ders kitapları ve ögretmen kılavuz kitaplarında kazanımlarla ilgili etkinlik örneklerinin büyük 
çoğunluğunun grup olarak gerçekleştirilmesi ve grupların kaçar öğrenciden oluşması gerektiği açıklanmıştır. Benzer şekilde, proje ve performans ödevleri hazırlanırken öğrencilerin grupla çalışmaya yönlendirilmesi belirtilmiştir (MEB, 2006). Bu açıklama ve öneriler işbirliğine dayalı öğrenme yöntemi ile aktif öğrenmenin gerçekleşeceğini göstermektedir.

$\mathrm{Bu}$ araştırma ile 6. sınıf matematik öğretim programında işbirliğine dayalı öğrenme yönteminin kullanılabilirliğine ilişkin öğretmen görüşlerinin programın alt boyutlarına dönük olarak analiz edilmesi amaçlanmaktadır. 6 . sınıf matematik öğretim programı ne kadar iyi hazırlanırsa hazırlansın, programın uygulayıcısı öğretmelerdir. Programın uygulanma sürecine yönelik öğretmen görüşlerinin belirlenmesi, program geliştirme ve değerlendirme süreci açısından önemli görülmektedir. Bu gerekçelere dayalı olarak araştırmada " 6 . sınıf matematik öğretim programında işbirliğine dayalı öğrenme yönteminin kullanılabilirliğine ilişkin öğretmen görüşleri; cinsiyet, meslekteki hizmet süresi, mezun olunan kurum, işbirliğine dayalı öğrenme yöntemiyle ilgili hizmet içi eğitim alma durumu, 6. sınıf matematik öğretim programıla ilgili hizmet içi eğitim alma durumu ve matematikle ilgili sürekli bir yayın izleme durumuna göre farklılaşmakta mıdır?" sorusuna cevap aranmaktadır.

\section{YÖNTEM}

\section{Araştırmanın Modeli}

Betimsel nitelikte olan bu araştırmada, ilköğretim okullarında uygulanmaya başlanan 6 . sinıf matematik öğretim programında işbirliğine dayalı öğrenme yönteminin kullanılabilirliği öğretmen görüşlerine dayalı olarak değerlendirilmeye çalışıldığı için araştırma modeli olarak tarama modeli kullanılmıştır.

\section{Evren ve Örneklem}

Araştırmanın evrenini, 2006-2007 öğretim yılı bahar döneminde, Eskişehir ilindeki ilköğretim okullarında görev yapmakta olan 177 matematik öğretmeni oluşturmaktadır. Bu kapsamda araştırmanın örneklemi, Eskişehir ili merkez ilçesinde bulunan ilköğretim okullarındaki 6. sınıfları okutan matematik öğretmenleri arasından rastlantısal olarak seçilen 101 matematik öğretmeninden oluşmaktadır. Araştırmanın örneklemini oluşturan öğretmenlerin özelliklerini belirten yüzdelik ve frekans (f) dağılımı Tablo 1 'de verilmiştir. 
Tablo 1. Araştırmanın örneklemini oluşturan öğretmenlerin özellikleri

\begin{tabular}{llcc}
\hline & & f & \% \\
\hline Cinsiyet & Bayan & 56 & 55.4 \\
Meslekteki Hizmet Süresi & Erkek & 45 & 44.6 \\
& $1-5$ yıl & 26 & 25.7 \\
& 6-10 yıl & 31 & 30,7 \\
Mezun Olunan Kurum & 10 yıldan fazla & 44 & 43,6 \\
& Eğitim Fakültesi & 36 & 35,6 \\
& Fen Edebiyat Fakültesi & 34 & 33,7 \\
I.D.Ö.Y. ile İlgili Hizmet İçi Eğitim & Diğer & 31 & 30,7 \\
& Alan & 37 & 36,6 \\
6. Sınıf Matematik Öğretim & Almayan & 64 & 63,4 \\
Programıla İlgili Hizmet İçi Eğitim & Alan & 74 & 73,3 \\
Matematikle İlgili Sürekli Yayın & Almayan & 27 & 26,7 \\
& İzleyen & 38 & 37,6 \\
& İzlemeyen & 63 & 62,4 \\
\hline
\end{tabular}

Tablo 1 incelendiğinde; öğretmenlerin cinsiyet ve mezun olunan kurum bakımından homojen bir dağılıma sahip oldukları görülmektedir. Ayrıca araştırmaya katılan öğretmenlerin \%43.6'sını 10 yıldan fazla meslekte hizmet süresine sahip öğretmenler oluşturmaktadır. Araştırmaya katılan öğretmenlerin İ.D.Ö.Y. ile ilgili hizmet içi eğitim alma durumları incelendiğinde, öğretmenlerin \%63.4'ünün hizmet içi eğitim almamış oldukları görülmektedir. Bu durum, 6 . sinıf matematik öğretim programın uygulayıcısı öğretmenlerin öğretim programının gereklerini yerine getirmek için İ.D.Ö.Y.'le ilgili bilgilendirilmeden ögretim programını uygulamaya başladıkları şeklinde yorumlanabilir. Tabloda, öğretmenlerin 6. sınıf matematik öğretim programılla ilgili hizmet içi eğitim alma durumları incelendiğinde, öğretmenlerin \%73.3'ünün hizmet içi eğitim aldıkları görülmektedir. $\mathrm{Bu}$ durum, öğretim programının hazırlık ve uygulama aşamalarında öğretmenlerin çoğuna ulaşıldığı şeklinde yorumlanabilir. Dolayısıyla, öğretmenlerin 6. sinıf matematik öğretim programın niteliğini bilerek öğretim programını uygulamaya başladıkları söylenebilir. Ögretmenlerin \%62.4'ünün ise matematikle ilgili sürekli bir yayın izlemediği belirlenmiştir. Değişen eğitim felsefelerinden ve öğretmenöğrenci rollerinden haberdar olmayan öğretmenlerin, yenilenen matematik öğretim programını uygularken önceki öğretim programlarında olduğu gibi öğretmen merkezli, ezberci bir eğitim anlayışını devam ettirme durumları ve alışmış oldukları yöntemleri kullanma eğiliminde oldukları muhtemeldir. 


\section{Veri Toplama Aracı}

Verilerin toplanması aşamasında araștırmacı tarafindan hazırlanan ve iki bölümden oluşan veri toplama aracı kullanılmıştır. Veri toplama aracının hazırlanmasında, öncelikle 6. sinıf matematik öğretim programı ve İ.D.Ö.Y.'le ilgili literatür taranmış, matematik öğretmenleriyle görüşülerek öğretim programının uygulanmasıyla ilgili görüşleri alınmıştır. Daha sonra, alanla ilgili yapılan araştırmalar ve tezler gözden geçirilerek örnek veri toplama araçları incelenmiş ve araştırmacı tarafından veri toplama aracının maddeleri taslak olarak yazılmıştır.

Veri toplama aracının kapsam geçerliğinin sağlanması için maddelerin 6. sınıf matematik öğretim programının beceri, öğrenme alanları, etkinlik, ilişkilendirme, ölçme ve değerlendirme öğelerini örneklemesine, maddelerin her birinin ölçmek istediği durumu en iyi derecede ölçmesine özen gösterilmiş ve uzman görüşlerine başvurulmuştur. Bunun için Anadolu Üniversitesi ve Eskişehir Osmangazi Üniversitesi'nde bulunan ve eğitim programları alanında çalışan öğretim üyelerinin görüşleri alınmış; bu görüşler doğrultusunda gerekli düzeltmeler yapılmıştır. Veri toplama aracının yapı geçerliğinin sağlanıp sağlanmadığ 1 programın beceri, etkinlik, ilişkilendirme ve değerlendirme alt boyutlarına ilişkin iç tutarlılık katsayıları hesaplanarak incelenmiştir. Bu katsayıların kabul edilebilir düzeyde bulunması, ölçme aracının homojenliğinin, dolayısıyla da yapı geçerliliğinin göstergesidir (Atılgan, Kan ve Doğan, 2007). Buna göre iç tutarlılık katsayıları; beceri için 0.73 , etkinlik için 0.64 , ilişkilendirme için 0.66 ve değerlendirme için 0.87 şeklinde hesaplanmış olup madde sayıları da göz önünde bulundurulduğunda veri toplama aracinın yap1 geçerliğinin sağlandığı kabul edilmiştir. Veri toplama aracı önce araştırma örneklemi dışında kalan ve 6 . sınıfları okutan 30 matematik öğretmenine uygulanarak güvenirlik katsayıları hesaplanmıştır. Araştırmada önce taslak olarak hazırlanan veri toplama aracı, daha sonra uzman görüşlerinin öneri ve eleştirileri doğrultusunda tekrar düzenlenerek uygulamaya hazır hale getirilmiştir.

Veri toplama aracının ilk bölümü araştırmayı oluşturan öğretmenlerin özelliklerini saptamaya yönelik kişisel bilgi formu niteliğindedir. İlk bölümün maddeleri arasında cinsiyet, meslekteki hizmet süresi, mezun olunan kurum, İ.D.Ö.Y.'le ilgili hizmet içi eğitim alınıp alınmadığı, 6. sınıf matematik öğretim programıyla ilgili hizmet içi eğitim alınıp alınmadığı, matematikle ilgili sürekli herhangi bir yayın izlenip izlenmediği soruları yer almaktadır. İkinci bölümde ise 6. sınıf matematik öğretim programında İ.D.Ö.Y.'ün kullanılabilirliğine ilişkin öğretmen görüşlerini saptamak amacıyla beşli likert tipi 18 madde bulunmaktadır. Öğretim programıyla 
ilgili öğretmen görüşleri öğretim programının beceri, öğrenme alanları, etkinlik, ilişkilendirme ve değerlendirme alt boyutlarıyla ilişkili olarak ele alınmıştır. Veri toplama aracında, 6. sınıf matematik öğretim programının beceri alt boyutuyla ilgili 5 madde, öğrenme alanları alt boyutuyla ilgili 1 madde, etkinlik alt boyutuyla ilgili 3 madde, ilişkilendirme alt boyutuyla ilgili 3 madde ve değerlendirme alt boyutuyla ilgili 6 madde yer almaktadır. Geçerlilik ve güvenirlik çalışmaları yapılan veri toplama aracının Cronbach Alpha katsayıs1 0.91 olarak bulunmuştur. Bulunan değer veri toplama aracının güvenirliği için oldukça yüksek bir değer olarak kabul edilmiştir.

\section{Verilerin Toplanması ve Analizi}

Araştırmada kullanılan veri toplama aracı, örnekleme alınan öğretmenlere araştırmacı tarafından uygulanmıştır. Bunun nedeni, örneklem grubunun veri toplama aracına ilgi göstermelerini sağlamak, onlardan gelebilecek soruları yantlamak ve verilerin eksiksiz toplanmasinı sağlamaktır. Uygulama sırasında öğretmenlere araştırmanın amacı hakkında bilgi verilmiş ve veri toplama aracını nasıl yanıtlamaları gerektiği açıklanmıştır. Uygulama sonrasında elde edilen verilerin analizinde SPSS 13.0 (Statistical Package for Social Science) programından yararlanılmıştır. Öncelikle, araştırmayı oluşturan öğretmenlerin özelliklerine göre çalışma örnekleminin durumu değerlendirilmiştir. Bunun için değişken düzeylerine ilişkin frekans ve yüzdelik dilimlerden yararlanılmıştır. Daha sonra, gerçekleştirilen Kolmogorov-Smirnov normallik testi sonucunda araştırmada ele alınan örneklemin normal dağılmadığına karar verilmiş ve parametrik olmayan testlerden Mann-Whitney U ve Kruskal Wallis testi kullanılarak, 6. sınıf matematik öğretim programında İ.D.Ö.Y.'ün kullanılabilirliğine ilişkin görüşlerin verilen değişkenlere göre farklılaşıp farklılaşmadığına bakılmıştır. Öğretmen görüşleri arasında anlamlı bir farklılık olup olmadığ 0.05 anlamlılık düzeyinde test edilmiştir.

\section{BULGULAR}

Bu bölümde, verilerin çözümlenmesi sonucunda elde edilen bulgulara ve yorumlara yer verilmiştir. Öncelikle, öğretmen görüşleri programın alt boyutlarına göre değerlendirilmiş, bunun için her bir alt boyuta ilişkin aritmetik ortalama ve standart sapma değerleri hesaplanmış ve sonuçlar Tablo 2'de sunulmuştur.

Tablo 2 incelendiğinde; en yüksek aritmetik ortalama puanına sahip boyutun beceri $(X=3,729)$ olduğu görülmektedir. $\mathrm{Bu}$ bölümü etkinlik $(X=3,541)$, değerlendirme $(X=3,467)$ ve ilişkilendirme $(X=3,281)$ boyutları izlemektedir. En düşük aritmetik ortalama puanına sahip boyutun ise öğrenme alanları $(X=3,228)$ olduğu saptanmıştır. $\mathrm{Bu}$ sonuç, öğretmenlerin 
İ.D.Ö.Y.'ü matematik dersinde kullanmaları sonucu yöntemin ilkelerinin gerçekleşmesi ve İ.D.Ö.Y.'ün öğrencilerde istenen becerilerin kazanılmasına yardımcı olmasından kaynaklanmış olabilir. Ayrıca, öğretmenler öğrenme alanlarının işlevsel olarak kullanılmamasından dolayı bu boyutla ilgili daha olumsuz görüşlere sahip olabilirler.

Tablo 2. Altıncı sinıf matematik ögretim programının alt boyutlarına iliş̧kin aritmetik ortalama ve standart sapma sonuçları

\begin{tabular}{lccc}
\hline Alt Boyutlar & N & Ortalama(X) & Standart sapma \\
\hline Beceri & 101 & 3,729 & 0,675 \\
Öğrenme Alanları & 101 & 3,228 & 1,094 \\
Etkinlik & 101 & 3,541 & 0,861 \\
İlişkilendirme & 101 & 3,281 & 0,855 \\
Değerlendirme & 101 & 3,467 & 0,876 \\
\hline
\end{tabular}

Programın alt boyutlarına yönelik öğretmen görüşlerine ilişkin bu bilgilerden sonra İ.D.Ö.Y.'ün 6. sınıf matematik öğretim programında kullanılabilirliğine ilişkin öğretmen görüşlerinin bazı değişkenlere göre farklılaşıp farklılaşmadığı araştırılmış ve sonuçlar aşağıda tablolar halinde sunulmuştur.

\section{Cinsiyete Göre Öğretmen Görüşleri Arasındaki Farklılıklar}

Araştırmanın örneklemini oluşturan ögretmenlerin 6. sınıf matematik öğretim programında İ.D.Ö.Y.'ün kullanılabilirliğiyle ilgili görüşlerinin cinsiyet değişkenine göre farklılaşıp farklılaşmadığı Mann-Whitney U testi ile araştırılmış ve sonuçlar Tablo 3 'te verilmiştir.

Tablo 3. Cinsiyete göre öğretmen görüşleri arasındaki farklılıklara ilişkin sonuçlar

\begin{tabular}{llcccccc}
\hline \multicolumn{1}{c}{ Cinsiyet } & & $\mathbf{N}$ & $\begin{array}{c}\text { Ort. } \\
\text { Rank }\end{array}$ & $\begin{array}{c}\text { Ranklar } \\
\text { Toplamı }\end{array}$ & $\mathbf{U}$ & $\mathbf{Z}$ & $\mathbf{p}$ \\
\hline Beceri & Bayan & 56 & 53,66 & 3005,00 & \multirow{2}{*}{1111,00} & $-1,024$ & 0,306 \\
& Erkek & 45 & 47,69 & 2146,00 & & & \\
Öğrenme & Bayan & 56 & 49,44 & 2768,50 & 1172,50 & $-0,620$ & 0,535 \\
Alanlar1 & Erkek & 45 & 52,94 & 2382,50 & & & \\
Etkinlik & Bayan & 56 & 52,47 & 2938,50 & 1177,50 & $-0,568$ & 0,570 \\
& Erkek & 45 & 49,17 & 2212,50 & & & \\
İlişkilendirme & Bayan & 56 & 50,56 & 2831,50 & 1235,50 & $-0,169$ & 0,866 \\
& Erkek & 45 & 51,54 & 2319,50 & & & \\
Değerlendirme & Bayan & 56 & 55,40 & 3102,50 & 1013,50 & $-1,687$ & 0,092 \\
& Erkek & 45 & 45,52 & 2048,50 & & & \\
Genel & Bayan & 56 & 52,21 & 2924,00 & 1192,00 & $-0,465$ & 0,642 \\
Ortalama & Erkek & 45 & 49,49 & 2227,00 & & & \\
\hline
\end{tabular}


Tablo 3 incelendiğinde, 6. sınıf matematik öğretim programının beceri, öğrenme alanları, etkinlik, ilişkilendirme, değerlendirme boyutları ve genel ortalama açısından İ.D.Ö.Y.'ün kullanılabilirliğine ilişkin öğretmen görüşleri arasında cinsiyet değişkenine göre anlamlı bir farklılık olmadığı görülmektedir. Buna göre, öğretmenlerin cinsiyetlerine bakılmaksızın benzer görüşlere sahip oldukları söylenebilir.

\section{Farklılıklar}

Meslekteki Hizmet Süresine Göre Öğretmen Görüşleri Arasındaki

Araştırmanın örneklemini oluşturan öğretmenlerin 6. sınıf matematik öğretim programında İ.D.Ö.Y.'ün kullanılabilirliğiyle ilgili görüşlerinin meslekteki hizmet süresi değişkenine göre farklılaşıp farklılaşmadığ Kruskal Wallis testi ile araştırılmış ve sonuçlar Tablo 4'te verilmiştir.

Tablo 4. Meslekteki hizmet süresine göre ögrretmen görüşleri arasındaki farklllıklara ilişkin sonuçlar

\begin{tabular}{|c|c|c|c|c|c|}
\hline & Hizmet Süresi & $\mathbf{N}$ & $\begin{array}{c}\text { Ort. } \\
\text { Rank }\end{array}$ & Ki kare & p \\
\hline \multirow[t]{3}{*}{ Beceri } & $1-5$ y1l & 26 & 51,58 & \multirow{3}{*}{0,184} & \multirow{3}{*}{0,912} \\
\hline & $6-10$ y1l & 31 & 49,15 & & \\
\hline & 10 yıldan fazla & 44 & 51,97 & & \\
\hline \multirow[t]{3}{*}{ Öğrenme Alanları } & $1-5 \mathrm{y} 11$ & 26 & 54,46 & \multirow{3}{*}{1,086} & \multirow{3}{*}{0,581} \\
\hline & $6-10 \mathrm{y} 11$ & 31 & 46,89 & & \\
\hline & 10 yıldan fazla & 44 & 51,85 & & \\
\hline \multirow[t]{3}{*}{ Etkinlik } & $1-5$ y1l & 26 & 61,31 & \multirow{3}{*}{4,426} & \multirow{3}{*}{0,109} \\
\hline & 6-10 y1l & 31 & 47,98 & & \\
\hline & 10 yıldan fazla & 44 & 47,03 & & \\
\hline \multirow[t]{3}{*}{ İlişkilendirme } & $1-5 \mathrm{y} 11$ & 26 & 52,69 & \multirow{3}{*}{4,158} & \multirow{3}{*}{0,125} \\
\hline & 6-10 y1l & 31 & 42,37 & & \\
\hline & 10 yıldan fazla & 44 & 56,08 & & \\
\hline \multirow[t]{3}{*}{ Değerlendirme } & $1-5$ y1l & 26 & 58,00 & \multirow{3}{*}{2,425} & \multirow{3}{*}{0,297} \\
\hline & 6-10 y1l & 31 & 51,18 & & \\
\hline & 10 yıldan fazla & 44 & 46,74 & & \\
\hline \multirow[t]{3}{*}{ Genel Ortalama } & $1-5$ y1l & 26 & 56,71 & \multirow{3}{*}{1,558} & \multirow{3}{*}{0,459} \\
\hline & 6-10 y1l & 31 & 47,10 & & \\
\hline & 10 yıldan fazla & 44 & 50,38 & & \\
\hline
\end{tabular}

Tablo 4'e göre, 6 . sınıf matematik öğretim programının beceri, öğrenme alanları, etkinlik, ilişkilendirme, değerlendirme boyutları ve genel ortalama açısından İ.D.Ö.Y.'ün kullanılabilirliğine ilişkin öğretmen görüşleri arasında meslekteki hizmet süresi değişkenine göre anlamlı bir farklılık olmadığ görülmektedir. Buna göre, öğretmenlerin meslekteki hizmet sürelerine bakılmaksızın benzer görüşlere sahip oldukları söylenebilir. 


\section{Mezun Olunan Kuruma Göre Öğretmen Görüșleri Arasındaki Farklılıklar}

Araştırmanın örneklemini oluşturan öğretmenlerin mezun olunan kurum değişkenine göre 6 . sınıf matematik öğretim programında İ.D.Ö.Y.'ün kullanılabilirliğiyle ilgili görüşlerinin farklılaşıp farklılaşmadığı Kruskal Wallis testi ile araştırılmış ve sonuçlar Tablo 5'te verilmiştir.

Tablo 5. Mezun olunan kuruma göre ögrretmen görüşleri arasındaki farklillklara ilişkin sonuçlar

\begin{tabular}{|c|c|c|c|c|c|}
\hline \multicolumn{2}{|c|}{ Mezun Olunan Kurum } & \multirow{2}{*}{$\frac{\mathbf{N}}{36}$} & \multirow{2}{*}{$\begin{array}{c}\begin{array}{c}\text { Ort. } \\
\text { Rank }\end{array} \\
61,94\end{array}$} & \multirow{3}{*}{$\begin{array}{c}\text { Ki kare } \\
9,891\end{array}$} & \multirow{3}{*}{$\frac{\mathbf{p}}{0,007}$} \\
\hline Beceri & Eğitim Fak. & & & & \\
\hline & Fen-Ed. Fak. & 34 & 40,07 & & \\
\hline \multirow{4}{*}{ Öğrenme Alanları } & Diğer & 31 & 50,27 & & \\
\hline & Eğitim Fak. & 36 & 58,75 & \multirow{3}{*}{10,475} & \multirow{3}{*}{0,005} \\
\hline & Fen-Ed. Fak. & 34 & 38,32 & & \\
\hline & Diğer & 31 & 55,90 & & \\
\hline \multirow[t]{3}{*}{ Etkinlik } & Eğitim Fak. & 36 & 63,49 & \multirow{3}{*}{10,554} & \multirow{3}{*}{0,005} \\
\hline & Fen-Ed. Fak. & 34 & 42,46 & & \\
\hline & Diğer & 31 & 45,87 & & \\
\hline \multirow[t]{3}{*}{ İlişkilendirme } & Eğitim Fak. & 36 & 60,28 & \multirow{3}{*}{16,908} & \multirow{3}{*}{$<0,001$} \\
\hline & Fen-Ed. Fak. & 34 & 34,32 & & \\
\hline & Diğer & 31 & 58,52 & & \\
\hline \multirow[t]{3}{*}{ Değerlendirme } & Eğitim Fak. & 36 & 63,71 & \multirow{3}{*}{10,820} & \multirow{3}{*}{0,004} \\
\hline & Fen-Ed. Fak. & 34 & 42,21 & & \\
\hline & Diğer & 31 & 45,89 & & \\
\hline \multirow[t]{3}{*}{ Genel Ortalama } & Eğitim Fak. & 36 & 63,89 & \multirow{3}{*}{15,750} & \multirow{3}{*}{$<0,001$} \\
\hline & Fen-Ed. Fak. & 34 & 36,16 & & \\
\hline & Diğer & 31 & 52,31 & & \\
\hline
\end{tabular}

Tablo 5 incelendiğinde, mezun olunan kurum değişkenine göre öğretmen görüşleri arasında anlamlı farklı1ıklar $(p<0.05)$ olduğu saptanmıştır. 6. sınıf matematik öğretim programının beceri, öğrenme alanları, etkinlik, ilişkilendirme, değerlendirme boyutları ve genel ortalama açısından İ.D.Ö.Y'ün kullanılabilirliğine ilişkin Eğitim Fakültesi mezunu öğretmenler, Fen-Edebiyat Fakültesi mezunu öğretmenlere göre daha olumlu düşüncelere sahiptir. 


\section{I.D.Ö.Y.'le İlgili Hizmet İçi Eğitim Alma Durumuna Göre Öğretmen Görüşleri Arasındaki Farklılıklar}

Araştırmanın örneklemini oluşturan öğretmenlerin 6. sınıf matematik öğretim programında İ.D.Ö.Y.'ün kullanılabilirliğiyle ilgili görüşlerinin İ.D.Ö.Y.'le ilgili hizmet içi eğitim alma durumu açısından farklılaşıp farklılaşmadığı Mann-Whitney U testi ile araştırılmış ve sonuçlar Tablo 6'da verilmiştir.

Tablo 6, öğretmenlerin İ.D.Ö.Y.'le ilgili görüşleri arasında hizmet içi eğitim alma durumuna göre anlamlı farkl1lıklar $(\mathrm{p}<0.05)$ olduğunu göstermektedir. Buna göre, hizmet içi eğitim alan öğretmenler 6 . sınıf matematik öğretim programının beceri, etkinlik, değerlendirme boyutları ve genel ortalama açısından İ.D.Ö.Y.'ün kullanılabilirliğine ilişkin daha olumlu düşüncelere sahiptirler. 6. sınıf matematik öğretim programın öğrenme alanları ve ilişkilendirmeyle ilgili boyutlarında hizmet içi eğitim alma durumuna göre öğretmen görüssleri arasında anlamlı bir farklılık olmadığı görülmektedir.

Tablo 6. İ.D.Ö.Y.'le ilgili hizmet içi eğitim alma durumuna göre öğretmen görüşleri arasındaki farklllıklara ilişkin sonuçlar

\begin{tabular}{|c|c|c|c|c|c|c|c|}
\hline \multicolumn{2}{|c|}{$\begin{array}{r}\text { İ.D.Ö.Y. İle İlgili Hizmet İçi } \\
\text { Eğitim }\end{array}$} & $\mathbf{N}$ & $\begin{array}{l}\text { Ort. } \\
\text { Rank }\end{array}$ & $\begin{array}{l}\text { Ranklar } \\
\text { Toplamı }\end{array}$ & $\mathbf{U}$ & $\mathbf{Z}$ & $\mathbf{p}$ \\
\hline Beceri & $\begin{array}{l}\text { Alan } \\
\text { Almayan }\end{array}$ & $\begin{array}{l}37 \\
64\end{array}$ & $\begin{array}{l}61,66 \\
44,84\end{array}$ & $\begin{array}{l}2281,50 \\
2869,50\end{array}$ & 789,50 & $-2,798$ & 0,005 \\
\hline Öğrenme & Alan & 37 & 56,11 & 2076,00 & 99500 & -1381 & 0167 \\
\hline Alanları & Almayan & 64 & 48,05 & 3075,00 & 995,00 & $-1,381$ & 0,167 \\
\hline Etkinlik & $\begin{array}{l}\text { Alan } \\
\text { Almayan }\end{array}$ & $\begin{array}{l}37 \\
64\end{array}$ & $\begin{array}{l}61,93 \\
44,68\end{array}$ & $\begin{array}{l}2291,50 \\
2859,50\end{array}$ & 779,50 & $-2,875$ & 0,004 \\
\hline İlişkilendirme & $\begin{array}{l}\text { Alan } \\
\text { Almayan }\end{array}$ & $\begin{array}{l}37 \\
64\end{array}$ & $\begin{array}{l}55,93 \\
48,15\end{array}$ & $\begin{array}{l}2069,50 \\
3081,50\end{array}$ & 1001,5 & $-1,296$ & 0,195 \\
\hline Değerlendirme & $\begin{array}{l}\text { Alan } \\
\text { Almayan }\end{array}$ & $\begin{array}{l}37 \\
64\end{array}$ & $\begin{array}{l}67,81 \\
41,28\end{array}$ & $\begin{array}{l}2509,00 \\
2642,00\end{array}$ & 562,00 & $-4,392$ & $<0,001$ \\
\hline Genel Ortalama & $\begin{array}{l}\text { Alan } \\
\text { Almayan }\end{array}$ & $\begin{array}{l}37 \\
64\end{array}$ & $\begin{array}{l}63,01 \\
44,05\end{array}$ & $\begin{array}{l}2331,50 \\
2819,50\end{array}$ & 739,50 & $-3,133$ & 0,002 \\
\hline
\end{tabular}

\section{Sınıf Matematik Öğretim Programıyla İlgili Hizmet İçi Eğitim Alma Durumuna Göre Öğretmen Görüşleri Arasındaki Farklılıklar}

Araştırmanın örneklemini oluşturan öğretmenlerin 6. sınıf matematik öğretim programında İ.D.Ö.Y.'ün kullanılabilirliğiyle ilgili görüşlerinin 6 . sınıf matematik öğretim programıyla ilgili hizmet içi eğitim alma durumu açısından farklılaşıp farklılaşmadığı Mann-Whitney U testi ile araştırılmış ve sonuçlar Tablo 7'de verilmiştir. 
Tablo 7 incelendiğinde, öğretmenlerin İ.D.Ö.Y.'le ilgili görüşleri arasında 6. sınıf matematik öğretim programıyla ilgili hizmet içi eğitim alma durumuna göre anlamlı farklılıklar $(\mathrm{p}<0.05)$ olduğu görülmektedir. Hizmet içi eğitim alan öğretmenler beceri, değerlendirme boyutları ve genel ortalama açısından daha olumlu düşüncelere sahiptirler. Öğrenme alanları, etkinlik ve ilişkilendirme boyutlarıyla ilgili hizmet içi eğitim alma durumuna göre öğretmen görüşlerinin farklılaşmadığı saptanmıştır.

Tablo 7. Programla ilgili hizmet içi eğitim alma durumuna göre öğretmen görüşleri arasındaki farklılıklara ilişkin sonuçlar

\begin{tabular}{llllllll}
\hline $\begin{array}{l}\text { 6. Sınıf Matematik Öğretim } \\
\text { Programıyla İlgili Hizmet İçi } \\
\text { Eğitim }\end{array}$ & $\mathbf{N}$ & $\begin{array}{l}\text { Ort. } \\
\text { Rank }\end{array}$ & $\begin{array}{l}\text { Ranklar } \\
\text { Toplamı }\end{array}$ & $\mathbf{U}$ & $\mathbf{Z}$ & $\mathbf{p}$ \\
\hline Beceri & Alan & 74 & 54,59 & 4039,50 & 733,50 & $-2,050$ & 0,040 \\
& Almayan & 27 & 41,17 & 1111,50 & & & \\
Öğrenme & Alan & 74 & 51,47 & 3808,50 & 964,50 & $-0,274$ & 0,784 \\
Alanları & Almayan & 27 & 49,72 & 1342,50 & & & \\
Etkinlik & Alan & 74 & 53,78 & 3979,50 & 793,50 & $-1,590$ & 0,112 \\
& Almayan & 27 & 43,39 & 1171,50 & & & \\
İlişkilendirme & Alan & 74 & 52,57 & 3890,00 & 883,00 & $-0,897$ & 0,370 \\
& Almayan & 27 & 46,70 & 1261,00 & & & \\
Değerlendirme & Alan & 74 & 56,30 & 4166,00 & 607,00 & $-3,394$ & 0,003 \\
& Almayan & 27 & 36,48 & 985,00 & & & \\
Genel Ortalama & Alan & 74 & 54,61 & 4041,00 & 732,00 & $-2,049$ & 0,040 \\
& Almayan & 27 & 41,11 & 1110,00 & & \\
\hline
\end{tabular}

\section{Matematikle İlgili Sürekli Yayın İzleme Durumuna Göre Öğretmen Görüşleri Arasındaki Farklılıklar}

Araştırmanın örneklemini oluşturan öğretmenlerin 6. sınıf matematik öğretim programında İ.D.Ö.Y.'ün kullanılabilirliğiyle ilgili görüşlerinin matematikle ilgili sürekli yayın izleme durumu açısından farklılaşıp farklılaşmadığı Mann-Whitney U testi ile araştırılmış ve sonuçlar Tablo 8'de verilmiştir.

Tablo 8. Matematikle ilgili sürekli yayın izleme durumuna göre öğretmen görüşleri arasındaki farklılıklara ilişkin sonuçlar

\begin{tabular}{|c|c|c|c|c|c|c|c|}
\hline \multicolumn{2}{|c|}{$\begin{array}{l}\text { Matematikle İlgili Sürekli } \\
\text { Yayın }\end{array}$} & \multirow{2}{*}{$\begin{array}{l}\mathbf{N} \\
38 \\
63\end{array}$} & \multirow{2}{*}{$\begin{array}{c}\begin{array}{c}\text { Ort. } \\
\text { Rank }\end{array} \\
60,00 \\
45,57\end{array}$} & \multirow{2}{*}{$\begin{array}{c}\begin{array}{c}\text { Ranklar } \\
\text { Toplamı }\end{array} \\
2280,00 \\
2871,00\end{array}$} & \multirow{2}{*}{$\frac{\mathbf{U}}{855,00}$} & \multirow{2}{*}{$\frac{\mathbf{Z}}{-2,412}$} & \multirow{2}{*}{$\frac{\mathbf{p}}{0,016}$} \\
\hline Beceri & $\begin{array}{l}\text { İzleyen } \\
\text { İzlemeyen }\end{array}$ & & & & & & \\
\hline $\begin{array}{l}\text { Öğrenme } \\
\text { Alanları }\end{array}$ & $\begin{array}{l}\text { İzleyen } \\
\text { İzlemeyen }\end{array}$ & $\begin{array}{l}38 \\
63\end{array}$ & $\begin{array}{l}56,16 \\
47,89\end{array}$ & $\begin{array}{l}2134,00 \\
3017,00\end{array}$ & 1001,0 & $-1,424$ & 0,154 \\
\hline Etkinlik & $\begin{array}{l}\text { İzleyen } \\
\text { İzlemeyen }\end{array}$ & $\begin{array}{l}38 \\
63\end{array}$ & $\begin{array}{l}61,22 \\
44,83\end{array}$ & $\begin{array}{l}2326,50 \\
2824,50\end{array}$ & 808,50 & $-2,746$ & 0,006 \\
\hline İlişkilendirme & İzleyen & 38 & 60,93 & 2315,50 & 819,50 & $-2,666$ & 0,008 \\
\hline
\end{tabular}




\begin{tabular}{llllllll}
\hline \multirow{3}{*}{ Değerlendirme } & İzlemeyen & 63 & 45,01 & 2835,50 & & & \\
& İzleyen & 38 & 68,92 & 2619,00 & 516,00 & $-4,783$ & $<0,001$ \\
& İzlemeyen & 63 & 40,19 & 2532,00 & & & \\
Genel & İzleyen & 38 & 63,58 & 2416,00 & 719,00 & $-3,351$ & 0,001 \\
Ortalama & İzlemeyen & 63 & 43,41 & 2735,00 & & \\
\hline
\end{tabular}

Tablo 8, öğretmenlerin görüşlerinde matematikle ilgili yayın izleme durumuna göre anlamlı farkl11ıklar $(p<0.05)$ olduğunu göstermektedir. Matematikle ilgili sürekli yayın izleyen öğretmenler beceri, etkinlik, ilişkilendirme, değerlendirme boyutları ve genel ortalama açısından 6. sınıf matematik öğretim programında İ.D.Ö.Y.'ün kullanılabilirliğine ilişkin daha olumlu fikirlere sahiptirler. Öğrenme alanları boyutunda ise öğretmen görüşleri arasında anlamlı farklılık olmadığı belirlenmiştir.

\section{TARTIŞMA ve SONUÇ}

$\mathrm{Bu}$ araştırmada, 6. sınıf matematik öğretim programının etkililiğini belirleyecek ve onun uygulayıcısı olan öğretmenlerin, programda işbirliğine dayalı öğrenme yönteminin kullanılabilirliğine ilişkin görüşleri, programın alt boyutlarına dönük olarak analiz edilmiştir $\mathrm{Bu}$ bağlamda, araştırma verilerinin analizinden ortaya çıkan sonuçlar açıklanmaktadır. Öğretmen görüşlerinin programın alt boyutlarına göre değerlendirilmesi sonucunda, en yüksek aritmetik ortalama puanına sahip boyutun beceri $(X=3,729)$, en düşük aritmetik ortalama puanına sahip boyutun ise öğrenme alanları $(\mathrm{X}=3,228)$ olduğu saptanmıştır.

Cinsiyet değişkenine göre öğretmen görüşleri arasında anlamlı bir farklılık bulunmamıştır. Bu sonuç, Bulut (2006)'un araştırmasında, öğretim programının eğitim durumları alt boyutuna ilişkin öğretmen görüşleri ve Yılmaz (2006)'ın yenilenen 5. sınıf matematik programı hakkında öğretmen görüşlerini belirlediği araştırmasıyla tutarlılık göstermektedir. Ancak, Gömleksiz (2005)'in, yeni ilköğretim programının uygulanması ve etkinliğine ilişkin öğretmen görüşlerini belirlediği araştırma sonuçlarıyla farklılık göstermektedir. Gömleksiz (2005) araştırmasında, yeni programın geneline ilişkin öğretmen görüşleri arasında cinsiyet değişkenine göre anlamlı bir farklılığın ortaya çıktığını saptamıştır. Ayrıca, Bulut (2006)'un araştırmasında da öğretim programın kazanım, kapsam ve değerlendirme alt boyutlarıyla ilgili öğretmen görüşlerinde cinsiyet değişkenine göre anlamlı farklılıklar ortaya çıkmıştır. Araştırma sonuçlarındaki bu farklılık, çalışma gruplarının farklı olmasından ve araştırmaların ilköğretim birinci kademeye yönelik olmasından kaynaklanmış olabilir.

Meslekteki hizmet süresi değişkenine göre öğretmen görüşleri arasında anlamlı bir farklılık bulunmamıştır. Genç öğretmenlerin öğretim yöntemleri 
hakkında daha güncel bilgilere sahip ve donanımlı olmaları, dolayısıyla 6 . sınıf matematik öğretim programında İ.D.Ö.Y.'ün kullanılabilirliğiyle ilgili daha olumlu düşüncelere sahip olmaları beklenmekteydi, ancak elde edilen bu sonucun düşündürücü olduğunu vurgulamak gerekmektedir. Özdemir (2005)'in araştırmasında da, öğretmenlerin kıdemlerine göre öğretim programıla ilgili bilgi sahibi olma, uygulama ve yeterlilik boyutlarına ilişkin görüşleri arasında anlamlı düzeyde farklılık olmadığı ortaya çıkmıştır. Bulut (2006)'un araştırmasında benzer şekilde, ilköğretim birinci kademe yeni öğretim programının kazanım, kapsam, eğitim durumu ve değerlendirmeye ilişkin öğretmen görüşleri arasında kıdem değişkenine göre farklı1ık bulunmamıştır. Orbeyi (2007)'nin çalışmasında da ilköğretim (1-5. sınıflar) matematik ögretim programının, kazanım ve içerik öğelerine ilişkin öğretmen görüşleri arasında mesleki deneyim değişkenine göre farklılık bulunamamıştır.

Mezun olunan kurum değişkenine göre öğretmen görüşleri arasında Eğitim Fakültesi mezunu öğretmenler lehine anlamlı farklılıklar bulunmuştur. Orbeyi (2007)'nin araştırma sonuçlarına göre, öğretmenlerin eğitim durumu özellikleri açısından, öğretim programının kazanım, içerik, öğretme-öğrenme süreci, değerlendirme boyutlarına yönelik görüşleri arasında anlamlı bir fark olmadığı belirlenmiştir. Ayrıca Özdemir (2005), Bulut (2006) ve Yılmaz (2006)'ın araştırma sonuçları da bu sonuç ile tutarlılık göstermektedir. Araştırma sonuçlarındaki bu farklılığın sebebi, araştırmaların ilköğretim birinci kademeye yönelik olması, çalışma grubunun farklı olması ve eğitim durumu gruplarının farklı biçimlerde belirlenmesi olabilir. Örneğin; Orbeyi (2007) eğitim durumu maddelerini, ön lisans ve lisans tamamlama, lisans mezunu ve diğer şeklinde belirlemiştir.

İ.D.Ö.Y.'le ilgili hizmet içi eğitim alan öğretmenlerin, 6. sınıf matematik öğretim programının beceri, etkinlik, değerlendirme boyutları ve genel ortalama açısından İ.D.Ö.Y.'ün kullanılabilirliğine ilişkin daha olumlu düşüncelere sahip oldukları saptanmıştır. İ.D.Ö.Y.'ün ilkeleri, teknikleri ve uygulanışıyla ilgili bilgiye sahip öğretmenlerin geleneksel yapıdaki anlayışın yerine İ.D.Ö.Y.'ü benimsemiş oldukları söylenebilir. 6. sınıf matematik öğretim programının getirdiği değerlendirme çalışmalarında İ.D.Ö.Y. kullanılması, geleneksel yöntemlerden farklı olarak daha gerçekçi değerlendirmenin yapılmasını sağlamış olabilir. Yöntemle ilgili bilgi sahibi öğretmenler, süreç değerlendirmenin İ.D.Ö.Y.'le daha kısa sürede ve sistematik bir şekilde gerçekleştirildiğini fark etmiş olabilir. Pesen (2005)'in araştırması da bu durumu desteklemektedir. Pesen (2005), öğretim programlarında İ.D.Ö.Y. ile ilgili açıklayıcı bilgilerin olmasının yararlı olacağını belirtmiştir. Yaşar, Gültekin, Türkkan, Yıldız ve Girmen (2005) 
tarafından yapılan araştırmada öğretmenler, yeni öğretim programını yeterince tanımama, yapılandırmacı anlayış hakkında yeterli bilgiye sahip olmama, sınıf mevcutlarının uygulamaya uygun olmaması, programdaki değerlendirme yöntemleri hakkında yeterli bilgiye sahip olamama gibi sorunlara "kesinlikle katıldıklarını" belirtmişlerdir.

6. sınıf matematik öğretim programıla ilgili hizmet içi eğitim alan öğretmenlerin, öğretim programının beceri, değerlendirme boyutları ve genel ortalama açısından İ.D.Ö.Y.'ün kullanılabilirliğine ilişkin daha olumlu düşüncelere sahip oldukları saptanmıştır. 6. sınıf matematik öğretim programının yaklaşımı, vizyonu ve öğeleriyle ilgili bilgiye sahip öğretmenlerin, programının kazandırmayı amaçladığı becerileri ve değerlendirme çalışmalarını İ.D.Ö.Y.'ü kullanarak yapmanın daha verimli sonuçlar ortaya çıkardığını düşündükleri söylenebilir. Ayrıca, öğrenme alanları, etkinlik ve ilişkilendirme boyutlarıyla ilgili hizmet içi eğitim alma durumuna göre öğretmen görüşlerinin farklılaşmadığı belirlenmiştir. $\mathrm{Bu}$ sonuç, hizmet içi çalışmalarda genel olarak 6. sınıf matematik öğretim programının yaklaşımı, vizyonu ve öğeleriyle ilgili bilgilere yer verilmesinden ve programının içeriğiyle ilgili detaylı bilgilere yer verilmemiş olmasından kaynaklanmış olabilir. Gözütok, Akgün ve Karacaoğlu (2005), Özdemir (2005), Yaşar, Gültekin, Türkkan, Yıldız ve Girmen (2005), Korkmaz (2006), Orbeyi (2007)'nin araştırma sonuçlarında da genel olarak, öğretmenlerin yeni öğretim programlarıyla ilgili bilgilenme düzeylerinin ve kısa süreli hizmet içi eğitim çalışmalarının yetersiz olduğu belirlenmiştir. Babadoğan ve Olkun (2005) çalışmalarında, yeni matematik öğretim programını uygulayan öğretmenlerin, eğitim durumunda ve değerlendirmede yeni teknikler kullanmaları gerektiğini ifade etmişlerdir. $\mathrm{Bu}$ nedenle, öğretmenlerin matematik öğretimi hakkında eğitilmeleri gerektiğini vurgulamışlardır.

Matematikle ilgili sürekli yayın izleyen öğretmenlerin, öğretim programının beceri, etkinlik, ilişkilendirme, değerlendirme boyutları ve genel ortalama açısından İ.D.Ö.Y.'ün kullanılabilirliğine ilişkin daha olumlu düşüncelere sahip oldukları saptanmıştır. Matematikle ilgili, güncel yayınlar izleyen öğretmenlerin matematik öğretim programlarındaki değişimlerden haberdar olmaları muhtemeldir. $\mathrm{Bu}$ öğretmenler geleneksel anlayıştan ziyade, öğrencinin çok yönlü gelişim gösterebileceği İ.D.Ö.Y.'ün 6. sınıf matematik öğretim programında kullanılabilirliğine daha çok inanıyor olabilirler.

Ayrıca, matematik öğretim programlarının uygulama süreçlerini inceleyen araştırma sonuçları da İ.D.Ö.Y.'ün programlarda kullanılmasıyla ilgili önemli sonuçlar sağlamaktadır. Sağlık (2007), pilot uygulanması 
yapılan matematik programıla ilgili araştırmasında, 6. sınıf geometri konularının öğretilmesinde kullanılan etkinliklerin uygulanma sürecini incelemiştir. Etkinlik temelli öğretimin kalıcılığı sağladığı ve grup çalışmasındaki olumlu etkileşim sonucunda etkinliklerin iyi seviyede gerçekleştiği belirlenmiştir. Toptaş (2007)'ın araştırmasında ise, ilköğretim 1. sınıf matematik dersi öğretim programında yer alan geometri alt öğrenme alanlarıyla ilgili öğrenme-öğretme sürecini incelenmiş ve dersin işleniş̧ sürecinde genellikle düz anlatım yönteminin kullanıldığını tespit etmiştir. Ayrıca, dersin işleniş sürecinde sınıf içi etkileşim ve iletişimin, genelde öğretmen-öğrenci arasında kurulduğu belirlenmiştir.

Araştırma sonunda ulaşılan tüm bulgulara dayanarak bazı öneriler geliştirilebilir. Öğretmen yetiştiren eğitim kurumlarında, İ.D.Ö.Y.'ün ve öğrenciyi etkin kılan öğretim yöntemlerinin nasıl kullanılacağına ilişkin hizmet öncesi eğitime ağırlık verilebilir. Ayrıca, staj yapan öğretmen adaylarına çağdaş yöntemleri ve yeni teknolojileri kullanarak ders anlatma olanakları sağlanabilir. İ.D.Ö.Y.'le ilgili hizmet içi eğitimler küçük gruplara yaşantı yoluyla verilebilir. Öğretmenlerin İ.D.Ö.Y.'ü uygulamada karşılaştıkları sorunlar sorgulanabilir ve sorunlara çözümler aranabilir. Ayrıca, hizmet içi eğitim çalışmalarının konu alanında uzman kişilerce verilmesi sağlanabilir. Milli Eğitim Bakanlığı ve üniversiteler yenilenen 6 . sınıf matematik öğretim programından en üst düzeyde verim alabilmek için kapsamlı hizmet içi eğitim çalışmaları, konferanslar, seminerler ve hatta sınıf içi uygulamalar düzenleyebilir. Öğretmenlere öğretim programının dayandığı ilkeler, vurguladığ öğretim yöntemleri, ölçme ve değerlendirme araçları konularında hizmet içi eğitim verilebilir. Matematik öğretmenlerinin İ.D.Ö.Y.'ün matematik öğretim programlarında kullanılabilirliğiyle olumlu düşüncelere sahip olması ve yöntemin kullanımının yaygınlaşması için üniversiteler veya Milli Eğitim Bakanlığı öğretme-öğrenme strateji ve yöntemlerini anlatan yayınları öğretmenlere ücretsiz olarak dağıtabilir. Yapılan konferanslar ve seminerler yayın olarak basılıp bunlara katılma imkânı olmayan öğretmenlere ulaştırılabilir. İ.D.Ö.Y.'ün 6. sınıf matematik öğretim programında kullanımına ilişkin, öğretmen kılavuz kitaplarında hem teorik hem uygulama içerikli ayrıntılı bilgiler verilebilir ve öğretmene yardımcı kaynak kitaplar hazırlanabilir. Ayrıca ders kitapları, kılavuz ve kaynak kitaplar öğretmenlere öğretim y1lı başlamadan verilerek öğretmenlerin öğretim programını uygulamaya yönelik hazırlık yapmaları sağlanabilir. İlköğretim okullarında matematik laboratuarları oluşturulup, grupların rahatça çalışmalarını sağlayacak biçimde tasarlanabilir. 


\section{KAYNAKLAR}

Açıkgöz, K.Ü. (1992). İşbirlikli öğrenme: kuram, araştırma, uygulama. Malatya: Uğurel Matbaası.

Arslan, A. ve Şahin, T.Y. (2004). "Oluş̧urmacı yaklaşıma dayalı işbirlikli öğrenmenin öğrencilerin duyuşsal öğrenmelerine etkileri”. XIII. Ulusal Ĕ̆itim Bilimleri Kurultayl, İnönü Üniversitesi Eğitim Fakültesi, Malatya.

Atılgan, H., Kan, A. ve Doğan, N. (2007). Eğitimde ölçme ve değerlendirme. Ankara: Anı Yayıncilik.

Bodner, G.M. (1986). Constructivism: A Theory of knowledge. Journal Chemical Education, 63 (10), 873-878.

Babadoğan, C. ve Olkun, S. (2005). Program development models and reform in Turkish primary School mathematics curriculum. International Journal For Mathematics Teaching And Learning. [Online]: Retrieved on 21 February 2007, at URL: http://www.cimt.plymouth.ac.uk/journal/default.htm

Bryant, D.P. ve Bryant, B.R. (1998). Using assistive technology adaptions to include students with learning disabilities in cooperative learning activities. Journal of Learning Disabilities, 31(1), 41-54.

Bulut, İ. (2006). "Yeni ilköğretim birinci kademe programlarının uygulamadaki etkililiğinin değerlendirilmesi", Yayınlanmamış Doktora tezi, Fırat Üniversitesi Sosyal Bilimler Enstitüsü, Elazığ.

Cheung, K.C. ve Taylor, R. (1991). Towards a humanistic constructivist model of science learning: Changing perspectives and research implications. Journal of Curriculum studies, 23 (1), 21-40.

Erdoğan, İ. (2002). Eğitimde yeni yönelimler (Ed: Ö. Demirel ve Z. Kaya), Öğretmenlik mesleğine giriş, Ankara: Pegem A Yayınc1l1k, 281-285.

Ersoy, Y. (2006). İlköğretim matematik öğretim programındaki yenilikler-I: Amaç, içerik ve kazanımlar. Illkögretim-online 5 (1), 30-44. [Online]:

http://ilkogretim-online.org.tr/vol5say1/index.htm adresinden 24 Kasim 2006 tarihinde indirilmiştir.

Ertmer, P.A. ve Newby, T.J. (1993). Behaviorism, cognitivism, constructivism: Comparing critical features from an instructional design perspective. Performance Improvement Quarterly, 6(4), 50-72.

Eşme, İ. (2005). Eğitim göstergeleri: çöküşün bozguna dönüşmesi. Cumhuriyet Bilim Teknik Dergisi, CBT 930. http://muratkaymak.blogcu.com/2395711/ adresinden 7 Şubat 2007 tarihinde indirilmiştir. 
Gömleksiz, M.N. (2005). Yeni ilköğretim programının uygulamadaki etkililiğinin değerlendirilmesi. Kuram ve Uygulamada Ĕ̆itim Bilimleri Dergisi, 5 (2), 339-384.

Gözütok, D., Akgün, Ö.E. ve Karacaoğlu, C. (2005). "İlköğretim programlarının öğretmen yeterlilikleri açısından değerlendirilmesi", Eğitimde Yansımalar: VIII. Yeni İlköğretim Programlarını Değerlendirme Sempozyumu, Erciyes Üniversitesi Eğitim Fakültesi Tekışık Eğitim Araştırma Geliştirme Vakfı, Kayseri.

Holloway, J.H. (1999). Caution: Constructivism Ahead. Educational Leadership, 57 (3), 85-86.

Korkmaz, İ. (2006). "Yeni ilköğretim programının öğretmenler tarafindan değerlendirilmesi”, Ulusal Sinıf Ö̆̆gretmenliği Kongresi, Ankara.

Linkona, T. (1992). Education for character: how our schools can teach respect and responsibility. New York: A Bantom Books.

McGlinn, J.E. (1991). Cooperative problem solving in mathematics: Beginning the process. The Clearing House, 65(1), 14-15.

MEB. (2006). Illköğretim matematik dersi 6. sinıf ögretim programı. Ankara: Devlet Kitapları Müdürlüğ̈̈, 7-27, 110-116.

Mulryan, M.C. (1992). Student passivity during cooperative small groups in mathematics. The Journal of Educational Research, 85(5), 261-272.

Olkun, S. ve Aydoğdu, T. (2003). Üçüncü uluslar aras1 matematik ve fen araştırması (TIMSS) nedir? Neyi sorgular? Örnek geometri soruları ve etkinlikler. İlköğretim-online 2(1), 28-35. [Online]:

http://ilkogretim-online.org.tr/vol2say1/v02s01d.htm adresinden 14 Şubat 2007 tarihinde indirilmiştir.

Olkun, S. (2006). Yeni öğretim programlarını inceleme ve değerlendirme raporu. İlköğretim-online 5(1), 96, 99, 105. [Online]: http://ilkogretimonline.org.tr/vol5sayl/index.htm adresinden 24 Kasim 2006 tarihinde indirilmiştir.

Olssen, M. (1996). Radical constructivism and its failings: Anti-realism and individualism. British Journal of Educational Studies, 44(3), 275-295.

Orbeyi, S. (2007). "İlköğretim matematik dersi öğretim programının öğretmen görüşlerine dayalı olarak değerlendirilmesi”, Yayınlanmamış Yüksek lisans tezi, Çanakkale Onsekiz Mart Üniversitesi Sosyal Bilimler Enstitüsü, Çanakkale.

Özdaş, A. (1996). Ülkemizdeki genel eğitim sorunları içerisinde matematik eğitimi ve sorunları. Anadolu Üniversitesi Eğitim Fakültesi Dergisi, 6(2), 55-69. 
Özdemir, S.M. (2005). "İlköğretim okullarındaki öğretmenlerin yeni ilköğretim programlarına (I-V. Sınıflar) ilişkin görüşleri”. XIV. Ulusal Eğitim Bilimleri Kongresi, Pamukkale Üniversitesi Eğitim Fakültesi, Denizli.

Pesen, C. (2005). "Yapılandırmacı yaklaşıma göre yeni ilköğretim matematik programının değerlendirilmesi”, Eğitimde Yansımalar: VIII. Yeni İlköğretim Programlarını Değerlendirme Sempozyumu, Erciyes Üniversitesi Eğitim Fakültesi Tekışık Eğitim Araştırma Geliştirme Vakfi, Kayseri.

Pesen, C. (2006). Yapılandırmacı öğrenme yaklaşımına göre matematik ögretimi. Ankara: Pegem A Yayınc1lık.

Phillips, D.C. (1995). The good, the bad and the ugly: The many faces of constructivism. Educational Researcher, 24(7), 5-12.

Sağlık, N. (2007). "Pilot uygulamaları yürütülen ilköğretim matematik programına yönelik etkinliklerin bazı geometri konularının öğretimi üzerindeki etkisi”. Yayınlanmamış Yüksek Lisans Tezi, Yüzüncü Yıl Üniversitesi Fen Bilimleri Enstitüsü, Van.

Şişman, M. (2002). Öğretmenliğe giriş. Ankara: Pegem A Yayıncılık.

Toptaş, V. (2007). "İlköğretim matematik dersi (1-5) öğretim programında yer alan 1. sınıf geometri öğrenme alanı öğrenme-öğretme sürecinin incelenmesi”. Yayınlanmamış Doktora Tezi, Gazi Üniversitesi Eğitim Bilimleri Enstitüsü, Ankara.

TTKB. (2005). Genel yaklaşım, Ankara.

http://ttkb.meb.gov.tr/ogretmen/modules.php?name=Downloads\&d_op=vie wdownload\&cid=48 adresinden 3 Ocak 2007 tarihinde indirilmiştir.

Willoughby, S. (1990). Mathematics education for a changing world. Alexandria, Virgina: Association for Supervision and Curriculum Development.

Yaşar, Ş., Gültekin, M., Türkkan, B., Yıldız, N. ve Girmen, P. (2005). "Yeni ilköğretim programlarının uygulanmasına ilişkin sınıf öğretmenlerinin hazırbulunuşluk düzeylerinin ve eğitim gereksinimlerinin belirlenmesi”, Ĕ̈itimde Yansımalar: VIII. Yeni İlkögretim Programlarını Değerlendirme Sempozyumu, Erciyes Üniversitesi Eğitim Fakültesi Tekışık Eğitim Araştırma Geliştirme Vakfı, Kayseri.

Yilmaz, T. (2006). "Yenilenen 5. sinıf matematik programı hakkında ögretmen görüşleri”. Yayınlanmamış Yüksek lisans tezi, Sakarya Üniversitesi Sosyal Bilimler Enstitüsü, Sakarya. 